Maria José Duarte Osis 1 Anibal Faúndes 1 Maria Helena de Sousa 1 Graciana Alves Duarte 1 Patricia Bailey ${ }^{2}$

\section{Fertility and reproductive history of sterilized and non-sterilized women in Campinas, São Paulo, Brazil}

\author{
Fecundidade e história reprodutiva de mulheres \\ laqueadas e não laqueadas de Campinas, \\ São Paulo, Brasil
}

1 Centro de Pesquisa das Doenças Materno-Infantis de Campinas. C. P. 6181, Campinas, $S P$

13081-970, Brasil.

mjosis@cemicamp.org.br

2 Family Health

International. P.O. Box

13950, Research Triangle Park, NC 27709, U.S.A.

\begin{abstract}
This article compares sterilized and non-sterilized women in relation to socio-demographic characteristics, reproductive history, and cohabitation status. Women from 30 to 49 years of age and residing in Campinas, São Paulo State, Brazil, were interviewed with a pre-tested and structured questionnaire: 236 women sterilized at least five years before the interview and 236 non-sterilized women. The sterilized women were significantly more likely to be married or cohabiting, to be younger when they began cohabiting, and to have been in the union longer than the non-sterilized women. They also began childbearing at an earlier age and had a history of more pregnancies and more live births than non-sterilized women. Factors associated with a history of 3 or more live births at the time of the interview were surgical sterilization, younger age at first childbirth, older age at the interview, recognition of fewer contraceptive methods, and lower per capita income. The article concludes that sterilization generally appears to be the consequence of higher fertility in a group of women who initiate childbearing early in life, although its role in preventing these women from having even larger families may also have a demographic impact.
\end{abstract}

Key words Fecundity; Tubal Sterilization; Pregnancy; Contraception

Resumo São comparadas as características sócio-demográficas, da história de co-habitação e da vida reprodutiva de mulheres laqueadas e não laqueadas. Com um questionário estruturado e pré-testado, entrevistaram-se 236 mulheres de 30 a 49 anos de idade, laqueadas há pelo menos cinco anos e o mesmo número de não laqueadas, emparelhadas por idade e local de residência. Entre as laqueadas, em comparação com as demais, foi maior a proporção de mulheres unidas, com mais anos de união e que começaram mais jovens a viver com um companheiro; com maior número de gravidez e filhos vivos, e que haviam tido o primeiro filho com menor idade. A análise por regressão logística apontou que ter feito laqueadura, ser mais jovem quando nasceu o primeiro filho, ter maior idade por ocasião da entrevista, referir conhecer um menor número de métodos contraceptivos e apresentar menor renda individual estavam associados ao maior número de nascidos vivos (3 ou mais). Concluiu-se que, apesar do possível impacto demográfico, a opção pela esterilização cirúrgica parece ser conseqüência de uma maior fecundidade no grupo de mulheres que iniciaram precocemente a vida reprodutiva.

Palavras-chave Fecundidade; Esterilização Tubária; Gravidez; Anticoncepção 


\section{Introduction}

Tubal ligation has become so popular in Brazil that it has become a "natural" part of the reproductive experience, as important as other events in the biological cycle, and a marker for the end of a woman's reproductive capability (Minella, 1998). Currently, tubal ligation is a widely disseminated and accepted contraceptive option, a trend which appears difficult to reverse.

The 1996 Demographic Health Survey (DHS) estimated that $40 \%$ of childbearing-age Brazilian women living with a partner were sterilized. Mean age at tubal ligation was 28.9 years, and $57 \%$ of sterilized women had undergone the procedure before age 30 . Tubal ligation was also more prevalent among women with up to 4 years of schooling and those with 3 or more children. On the other hand, the contraceptive pill was the most commonly used method among more educated women and those with up to 2 children (BEMFAM/Macro International, 1997).

Historically, Brazilian women have faced difficulties accessing a wider range of contraceptive methods, reflecting Brazil's socioeconomic and political context in the 1960s, 70s, and 80s and physicians' unfamiliarity with (and lack of training in) the provision of methods other than oral contraceptives or female sterilization (Faria, 1989; Martine, 1996). The considerable demand for surgical sterilization has frequently been ascribed to this lack of access (Berquó \& Arilha, 1995; Hardy et al., 1993, 1996; Schor et al., 2000; Vieira, 1994). Meanwhile, the option for sterilization may be seen as the only choice by women who have experienced early and unplanned initiation of their sexual and reproductive life, who have more children than they want, and who were unaware of how to control their fertility (Serruya, 1996; Minella, 1998; Osis, 1999, 2001).

This paper compares the reproductive life histories of sterilized and non-sterilized women of the same age. Potential differences between these groups were analyzed with regard to the women's socioeconomic characteristics and cohabitation and reproductive history. Factors associated with the number of live births were also evaluated.

\section{Material and methods}

This study was a cross-sectional populationbased survey of 472 women, ages 30 through 49 years, residing in the municipality of Campi- nas, São Paulo State, Brazil, in 1996. The sample was divided evenly between sterilized and non-sterilized women.

Cluster sampling was performed, randomly selecting 100 census tracts, with an average monthly household income of up to approximately US\$ 910 (US\$ $1=\mathrm{R} \$ 1$ ). Interviewers were given a map of each census tract with a form especially designed to record all addresses and all women aged 30 to 49 residing in the tract.

Using this procedure, 2,860 women 30-49 years of age were identified in 7,367 households, but only 2,476 could be contacted. Of these, 128 refused and 2,348 agreed to answer a checklist designed to assess the household's socioeconomic status and women's sterilization status. Among the women who agreed to answer, 961 reported being sterilized, 794 of whom had been sterilized for at least 5 years. In addition to the 1,382 women who reported not being sterilized, 3 were unaware of whether they had been sterilized, and the information was missing for 2 women.

After the interviewer systematically canvassed a census tract, she selected two or occasionally three pairs of women: The first woman to be interviewed was the first sterilized woman who was identified and recorded in the form filled out by the interviewer. This woman was matched with the next non-sterilized woman identified in the tract whose age was within two years that of the sterilized woman. The same procedure was used to select and interview the second pair of women in each tract. In 36 tracts, three pairs of women were selected for interviewing in order to reach the necessary sample size. A structured and pre-tested questionnaire was used to collect data.

A bivariate analysis compared sterilized and non-sterilized women according to the following variables: marital status; duration of cohabitation; age at which cohabitation began; number of pregnancies, abortions, live births, stillbirths, and children currently alive; and woman's age at the first and last childbirth. Logistic regression was conducted in a second stage of data analysis. Sterilization versus nonsterilization was treated as a possible predictive variable in the model, together with marital status, employment, active religion, ethnicity, per capita income, years of schooling, number of abortions, woman's current age (continuous), age at first birth (continuous), and two scores concerning knowledge (of surgical sterilization and other contraceptive methods). The latter two variables were created as continuous scores, based on information obtained during focus groups (Krueger, 1994) that were conduc- 
ted to develop the questionnaire. More details about definition of the scores are provided in Osis et al. (1999).

SPSS-PC and Epi Info 6.0 were used to compare the socio-demographic characteristics and reproductive history of the two groups. The chi-squared and Student's t tests (Armitage, 1974) were used to measure statistical significance. Since the sterilized women had more live births than non-sterilized women, a multiple regression model (Hosmer \& Lemeshow, 1989) was developed to determine the association between a series of possible predictive variables and the number of live births, dichotomized as less than 3 live births and 3 or more. This multiple regression analysis was performed with forward selection of the variables and using a significance level of $5 \%$.

Sterilized and non-sterilized women participating in the study were similar in socioeconomic status. Most women in the two groups (64.9\% and $71.4 \%$, respectively) belonged to classes $\mathrm{C}, \mathrm{D}$, or $\mathrm{E}$. There was no statistically significant difference between women who participated in the study and women who were not included in the sample: $68 \%$ from each group belonged to socioeconomic classes $\mathrm{C}, \mathrm{D}$, or $\mathrm{E}$.

\section{Results}

There were significant differences between sterilized and non-sterilized women in relation to marital status, duration of cohabitation, and age at which cohabitation began. Three-fourths of the sterilized women were married or cohabiting as compared to fewer than $60 \%$ of the non-sterilized women. Less than $1 \%$ of sterilized women as compared to $18 \%$ of non-sterilized women were single. More than $40 \%$ of sterilized women had been in a marital union or the equivalent for 20 years or more as compared to fewer than $30 \%$ in the non-sterilized group. Among sterilized women, $71 \%$ were 24 or younger when they were married or began cohabiting as compared to less than $60 \%$ of non-sterilized women (Table 1).

Sterilized women had significantly more pregnancies, live births, and children currently alive than non-sterilized women. Approximately three-fourths (76\%) of sterilized women had a history of 3 or more pregnancies, and $69 \%$ had a history of at least 3 live births, compared to $33 \%$ and $24 \%$, respectively, in the other group. The proportion of sterilized women with a history of 3 or more live births at the time of the interview was approximately 3 times that of non-sterilized women (Table 2).
More than one-third of the women who had undergone tubal ligation were less than 20 years of age at first childbirth; meanwhile, about onefifth $(21 \%)$ of non-sterilized women gave birth to their first child by that age. Mean age at first delivery was significantly lower for sterilized as compared to non-sterilized women. However, there was no significant difference between the groups in relation to woman's age at last delivery (birth of the youngest child). Mean age was about 28 years in both groups (Table 3 ).

Table 4 shows the variables associated with 3 or more live births in a logistic regression analysis. The odds of 3 or more live births according to the logistic regression analysis were 7.00 if the woman was sterilized. As age at first birth increased, the odds of 3 live births decreased (odds ratio $=0.79$ ), but the older a woman was at interview the more likely she was to have a "larger" family. Compared with women who were familiar with 4 or fewer contraceptive methods, women who were familiar with more than 4 methods were less likely to have 3 or more live births (odds ratio $=0.38$ ).

Table 1

Percentage of sterilized and non-sterilized women according to marital status, duration of cohabitation, and age at which cohabitation began.

\begin{tabular}{|c|c|c|c|}
\hline Characteristics & $\begin{array}{l}\text { Sterilized } \\
(\%)\end{array}$ & $\begin{array}{c}\text { Non-sterilized } \\
\text { (\%) }\end{array}$ & $p^{\star}$ \\
\hline Marital status & & & $<0.001$ \\
\hline Single & 0.4 & 18.2 & \\
\hline Married & 75.8 & 58.9 & \\
\hline Cohabiting & 12.3 & 12.7 & \\
\hline Separated/divorced & 11.4 & 10.2 & \\
\hline $\begin{array}{l}\text { Duration of marriage/ } \\
\text { cohabitation (years) }\end{array}$ & & & $<0.001$ \\
\hline Without partner & 11.9 & 28.4 & \\
\hline$\leq 4$ & 4.2 & 5.5 & \\
\hline $5-9$ & 4.2 & 8.9 & \\
\hline $10-14$ & 11.4 & 12.7 & \\
\hline $15-19$ & 25.4 & 16.5 & \\
\hline$\geq 20$ & 42.4 & 28.0 & \\
\hline Total number of women & 236 & 236 & \\
\hline $\begin{array}{l}\text { Age cohabitation } \\
\text { began (years) }\end{array}$ & & & $<0.003$ \\
\hline$\leq 19$ & 33.7 & 18.3 & \\
\hline $20-24$ & 37.5 & 39.6 & \\
\hline $25-29$ & 16.8 & 19.5 & \\
\hline$\geq 30$ & 12.0 & 22.5 & \\
\hline Total number of women & 236 & 169 & \\
\hline
\end{tabular}

* Pearson's chi-squared test. 
Table 2

Percentage of sterilized and non-sterilized women, by reproductive history.

\begin{tabular}{|c|c|c|c|}
\hline Reproductive history & $\begin{array}{c}\text { Sterilized } \\
(\%)\end{array}$ & $\begin{array}{c}\text { Non-sterilized } \\
(\%)\end{array}$ & $p^{*}$ \\
\hline Pregnancies & & & $<0.001$ \\
\hline None & 0.0 & 16.5 & \\
\hline 1 & 0.4 & 20.3 & \\
\hline 2 & 23.3 & 30.1 & \\
\hline 3 & 38.6 & 14.8 & \\
\hline$\geq 4$ & 37.7 & 18.2 & \\
\hline Abortions & & & 0.472 \\
\hline None & 73.3 & 74.6 & \\
\hline 1 & 19.9 & 21.2 & \\
\hline$\geq 2$ & 6.8 & 4.2 & \\
\hline Live births & & & $<0.001$ \\
\hline None & 0.0 & 20.3 & \\
\hline 1 & 0.8 & 23.3 & \\
\hline 2 & 30.5 & 32.6 & \\
\hline$\geq 3$ & 68.6 & 23.7 & \\
\hline Stillbirths & & & $1.000 * \star$ \\
\hline None & 94.9 & 94.9 & \\
\hline$\geq 1$ & 5.1 & 5.1 & \\
\hline Children currently alive & & & $<0.001$ \\
\hline None & 0.0 & 21.2 & \\
\hline 1 & 0.8 & 23.7 & \\
\hline 2 & 33.5 & 32.6 & \\
\hline$\geq 3$ & 65.7 & 22.5 & \\
\hline Total number of women & 236 & 236 & \\
\hline
\end{tabular}

* Pearson's chi-squared test.

** Chi-squared test with Yates' correction.

Women with monthly incomes above US\$ 300 had a $55 \%$ decreased odds of 3 or more live births (odds ratio $=0.45$ ).

\section{Discussion}

The results indicate that sterilized women displayed more live births than non-sterilized women of the same age. Moreover, sterilization versus non-sterilization showed the greatest association with number of live births in the multiple regression analysis. It would be illogical for sterilization to have caused the higher number of live births in this group of women. It is more likely that the high number of live births at the same age led these women to opt for sterilization. The association between more limited knowledge of contraceptive methods and higher number of live births suggests that these women lacked the necessary information to plan their families in advance, and that surgical sterilization was the consequence of their limited capacity to plan the number of their children.

For the majority of sterilized women with partners, earlier initiation of cohabitation and younger age at first childbirth can be expected to have contributed to larger families. It can be argued that non-sterilized women may still have more live births in the future, while sterilized women will not. This is a real possibility, since two of the non-sterilized women were pregnant and more than $20 \%$ had never had a child, although $18 \%$ were single. But the difference between the two groups was so large that it would be highly unlikely that the non-sterilized women would ever reach the same number of live births as sterilized women, especially considering that the time since the last live birth was the same in both groups.

These results suggest that the high surgical sterilization rate may not have been the main cause of the rapid fertility decline observed in Brazil. According to this study, it appears that this demographic change resulted at least partially from women's personal decision to reduce the size of their families, regardless of the means. According to the 1996 DHS (BEMFAM/ Macro International, 1997), approximately 50\% of Brazilian women over 35 were sterilized. This study shows that (at least in the population sampled for this study) another $50 \%$ consisted of women who had successfully controlled their fertility and were having fewer children than those who resorted to sterilization. Moreover, more of them had remained without partners, at least up to the age when their sterilized counterparts had already ended their childbearing cycle. Other studies (Minella, 1998; Serruya, 1996) have already shown that sterilized women were more likely to experience difficulty in controlling their fertility. Compared to users of reversible contraceptive methods, sterilized women tend to focus their life projects on motherhood (Osis, 2001). These findings may have policy implications, suggesting that changing cultural attitudes towards low fertility and gender roles is more important than encouraging the use of such an effective method as surgical sterilization (Perpétuo \& Aguirre, 1998).

On the other hand, it can be argued that the large group of women who resorted to tubal ligation might have continued having children if this method had not been available to them; 
they were thus contributing to the country's fertility decline and reducing the gap between them and those who had been able to control their fertility since early in life.

It is interesting that schooling was not associated with more live births in this study, but specific knowledge on contraception was, suggesting that formal education may not be as an important determinant of fertility as the content that is included in the school program and the information women received regarding contraception.

It can also be argued that it is not appropriate to include single women in the analysis, since their chances of being sterilized are minimal. But to make the decision to live without a permanent formal partner is part of the set of attributes that characterize the group of women age 30 or over who had not been sterilized. To characterize this group of women was exactly the purpose of this analysis. Moreover, marital status was not significantly associated with the number of live births in the multiple regression analysis.

The association between younger age at first childbirth and more live births is already well known (Pebley et al., 1982). To the best of our knowledge, what has not been documented is the association between early first childbirth and subsequent surgical sterilization. The data presented here strongly suggest that in order to reduce the number of young women who choose surgical sterilization over equally effective but reversible methods, it is necessary to act early in life. Young men and women should have quality education and services that provide them the means to make their own sexual and family planning decisions from the beginning of their reproductive years (Bailey et al., 2001; Mellanby et al., 1995). Otherwise, they will be more likely to have more children than they want before resorting to surgical sterilization.
There is no doubt that recent family planning legislation has greatly improved the access to surgical sterilization in the Brazilian public health system (Brasil, 1997) and reduced the discrimination and distortions observed before the law was enacted (Barroso, 1984; Berquó \& Arilha, 1995; Hardy et al., 1993, 1996; Osis et al., 1991; Vieira \& Ford, 1996). Nevertheless, it is not sufficient for people to have guaranteed free and informed decisions related to contraception. It is also necessary to provide adequate counseling on sexual and reproductive rights and health beginning in early adolescence, when women's life and reproductive projects are often already defined.

Table 3

Percentage of sterilized and non-sterilized women, by age at first and last birth.

\begin{tabular}{lccc}
\hline Women's age (years) & Sterilized (\%) & Non-sterilized (\%) & $\mathbf{p}^{*}$ \\
\hline At first birth & & \\
$\quad \leq 19$ & 36.0 & 21.3 & 41.0 \\
$20-24$ & 42.4 & 37.8 & $<0.001$ \\
$\geq 25$ & 21.6 & $23.8(5.3)$ & \\
Mean (SD) & $21.4(4.1)$ & $188+$ & \\
Total number of women & 236 & & \\
& & & \\
At last birth & 19.6 & 31.1 & \\
$\leq 24$ & 46.4 & 46.3 & \\
$25-29$ & 34.0 & $28.8(5.1)$ & \\
$\geq 30$ & $28.4(4.5)$ & 190 & \\
Mean (SD) & 235 & & \\
Total number of women & & &
\end{tabular}

* Student's t test.

** 39 women had never had a pregnancy; information missing for 2 women,

2 were pregnant at the time of interview, and 5 had been pregnant

but had never had a live birth.

Table 4

Logistic regression analysis for 3 or more live births $(n=358)$ *.

\begin{tabular}{|c|c|c|c|c|}
\hline Variables & Coef. & SE Coef. & $\mathbf{p}$ & OR \\
\hline Contraceptive method used (tubal ligation) & 1.945 & 0.284 & $<0.001$ & 7.00 \\
\hline Knowledge of contraceptive methods (> 4) score & -0.973 & 0.287 & $<0.001$ & 0.38 \\
\hline Woman's age at first birth (years) & -0.230 & 0.035 & $<0.001$ & 0.79 \\
\hline Woman's current age (years) & 0.112 & 0.019 & $<0.001$ & 1.12 \\
\hline Per capita monthly income (US\$ 300.00) & -0.797 & 0.278 & $<0.005$ & 0.45 \\
\hline
\end{tabular}

* Excluded 114 women that had 1 or more variable with missing value. Coef. = Estimated coefficient in the regression model; SE Coef. = Standard error of estimated coefficient; $p=$ Descriptive level; OR = Adjusted odds ratio. 


\section{Acknowledgements}

The authors would like to thank the Women's Studies Project in Brazil, under the United States Agency for International Development (USAID), through Family Health International (FHI), for the financial support to conduct this study.

\section{References}

ARMITAGE, P., 1974. Statistical Methods in Medical Research. 3rd Ed. New York: John Wiley and Sons.

BAILEY, P. E.; BRUNO, Z. V.; BEZERRA, M. F.; QUEIROZ, I.; OLIVEIRA, C. M. \& CHEN-MOK, M., 2001. Adolescent pregnancy 1 year later: The effects of abortion vs. motherhood in Northeast Brazil. Journal of Adolescent Health, 29:223-232.

BARROSO, C., 1984. Esterilização feminina: Liberdade e opressão. Revista de Saúde Pública, 18:170-180.

BEMFAM (Sociedade Civil Bem-Estar Familiar no Brasil) /MACRO INTERNATIONAL, 1997. Pesquisa Nacional sobre Demografia e Saúde, 1996. Rio de Janeiro: BEMFAM/Macro International.

BERQUÓ, E. \& ARILHA, M., 1995. Esterilização: Sintoma Social. Relatório Final de Pesquisa. Campinas: Núcleo de Estudos da População, Universidade Estadual de Campinas.

BRASIL, 1997. Lei no 9.263. Brasília: Diário Oficial da União, 20 ago.

FARIA, V. E., 1989. Políticas de governo e regulação da fecundidade: Conseqüências não antecipadas e efeitos perversos. Ciências Sociais Hoje, pp. 62-103.

HARDY, E.; BAHAMONDES, L.; OSIS, M. J. D.; COSTA, R. G. \& FAÚNDES, A., 1996. Risk factors for tubal sterilization regret, detectable before surgery. Contraception, 54:159-162.

HARDY, E.; OSIS, M. J. D.; FAÚNDES, A.; ALVES, G. \& PINOTTI, J. A., 1993. A laqueadura tubária precoce e durante cesárea. Dimensões atuais e fatores que a determinam. Revista de Ginecologia e Obstetricia de São Paulo, 4:70-76.

HOSMER, D. W. \& LEMESHOW, S., 1989. Applied Statistical Regression. New York: John Wiley and Sons.

KRUEGER, R. A., 1994. Focus Groups: A Practical Guide for Applied Research. 2nd Ed. Thousand Oaks: Sage Publications.

MARTINE, G., 1996. Brazil's fertility decline, 1965-95: A fresh look at key factors. Population and Development Review, 22:47-75.

MELLANBY, A. R.; PHELPS, F. A.; CRICHTON, N. J. \& TRIPP, J. H., 1995. School sex education: An experimental programme with educational and medical benefit. $B M J, 311: 414-420$.

MINELLA, L. S., 1998. Aspectos positivos e negativos da esterilização tubária do ponto de vista de mulheres esterilizadas. Cadernos de Saúde Pública, 14(Sup. 1):69-79.
OSIS, M. J. D., 1999. Esterilização e gravidez na adolescência: Fatores interrelacionados. In: Seminário Gravidez na Adolescência (E. M. Vieira, M. E. L. Fernandes, P. Bailey \& A. Mckay, org.), pp. 6773, São Paulo: Associação Saúde da Família.

OSIS, M. J. D., 2001. Laqueadura e Representações Acerca da Sexualidade e do Papel Reprodutivo. Tese de Doutorado, São Paulo: Faculdade de Saúde Pública, Universidade de São Paulo.

OSIS, M. J. D.; FAÚNDES, A.; SOUSA, M. H. \& BAILEY, P., 1999. Conseqüências do uso de métodos anticoncepcionais na vida das mulheres: $\mathrm{O}$ caso da laqueadura tubária. Cadernos de Saúde Pública, 15:521-532.

OSIS, M. J. D.; HARDY, E.; SIMÕES, I. R. S.; VERA, S. \& FAÚNDES, A., 1991. A laqueadura tubária nos serviços de saúde do Estado de São Paulo. Revista de Ginecologia e Obstetricia de São Paulo, 1:195-204.

PEBLEY, A. R.; CASTERLINE, J. B. \& TRUSSEL, J., 1982. Age at first birth in 19 countries. International Family Planning Perspectives, 8:2-7.

PERPÉTUO, I. H. O. \& AGUIRRE, M. A. C., 1998. O papel da esterilização feminina nos diferenciais sócio-econômicos do declínio da fecundidade no Brasil. In: XI Encontro Nacional de Estudos Populacionais da Associação Brasileira de Estudos Populacionais (ABEP), Anais, pp. 2997-3023, Caxambú: ABEP.

SCHOR, N.; FERREIRA, A. F.; MACHADO, V. L.; FRANÇA, A. P.; PIROTTA, K. C. M.; ALVARENGA, A. T. \& SIQUEIRA, A. A. F., 2000. Mulher e anticoncepção: Conhecimento e uso de métodos anticoncepcionais. Cadernos de Saúde Pública, 16:377-384.

SERRUYA, S., 1996. Mulheres Esterilizadas: Submissão e Desejo. Belém: Universidade Federal do Pará/Universidade do Estado do Pará.

VIEIRA, E. M., 1994. A esterilização de mulheres de baixa renda em região metropolitana do sudeste do Brasil e fatores ligados à sua prevalência. $R e$ vista de Saúde Pública, 28:440-448.

VIEIRA, E. M. \& FORD, N. J., 1996. The provision of female sterilization in São Paulo, Brazil: A study among low income women. Social Science and Medicine, 42:1427-1432.

Submitted on October 4, 2002

Final version resubmitted on April 1, 2003

Approved on May 22, 2003 